\title{
Does Profit Still Matter? The Implementation of Buddhist Ideas to Contemporary Business: Theory and Practice
}

\begin{abstract}
The subject matter of this paper is Buddhist economics in theory and practice. The goal is to point out the main concepts of Buddhist economics, which is different from Western mainstream economics, and then explain how applying Buddhist teachings to business can possibly improve societal well-being and the condition of the natural environment. The main contribution of the article is twofold. Firstly, it aims to plumb the literature to identify characteristics of Buddhist economics, which is a relatively new field. Secondly, it compares Buddhist enterprises to relatively well-known social enterprises, showing the main differences between them. "Buddhist ideas in practice" are illustrated by examples of such companies as Benefit System or Patagonia. The main conclusion is that money and wealth are allowed in Buddhism, but religion reminds people not to become attached to their possessions and to share them with others. Examples described in the paper lead to an awareness that economic activity can be a means to a noble life. New criteria of assessment of business success including social engagement and care for the environment should be created. Thus, deep institutional changes which redefine the roles and duties of business would be required. The paper is based on literature, documents and online sources. The research methods used are the critique of literature covering the subject matter, comparative analysis and elements of case studies.
\end{abstract}

Keywords: Buddhism; Buddhist economics; Buddhist enterprise; heterodox economics; mainstream economics; social enterprise

Received: 11 June 2019

Accepted: 17 May 2020

\section{Suggested citation:}

Tusińska, M. (2020). Does Profit Still Matter? The Implementation of Buddhist Ideas to Contemporary Business: Theory and Practice. Przedsiębiorczość - Edukacja [Entrepreneurship Education], 16(1), 388-400. doi: 10.24917/20833296.161.31

\section{Introduction}

Any religion, including Buddhism, is perceived as a factor forming ethical attitudes through the transfer of certain values which become a guide to individual action and exert an impact 
on standards in the whole of society. Here, the author does not pretend to consider the relations between religion and the performance of the whole economy, rather issues concerning the influence of Buddhist values on enterprises (not necessarily operating in Buddhist countries). The goal of the paper is threefold: to point out the main concepts of Buddhist economics as orthodox economics, and then explain the difference between Buddhist enterprises and social enterprises. In turn, the presentation of the activities of selected enterprises is intended to show how applying Buddhist teachings to business can possibly improve societal well-being and the condition of the natural environment.

Any activity of a Buddhist enterprise does not see profit as the principal goal, instead, the priority is to serve the community in a wider sense (Zsolnai, 2016). Due to the similarity of objectives, it may seem that Buddhist enterprises are the same as social enterprises. The thesis set out here is that this congruity of goals does not unambiguously determine the common identity of Buddhist and social enterprises.

Buddhist ideas are not very popular in Europe, thus a reference to them in the context of economics is a novelty. Moreover, Buddhist economics seems to be a relatively new field. It has been discussed by E.F. Schumacher (1966; 1973), P.A. Payutto (1994), S. Inoue (1997), P. Daniels (2007, 2010), Dalai Lama and H. van den Muyzenberg (2009), L. Zsolnai (2015, 2016), S.G. Tideman (2016), J. Magnuson (2016), C. Brown (2017), and Brown and Zsolnai (2018). Their views constitute the theoretical foundation of the article. The paper is based on the literature, documents and online sources and the research methods used are a critique of the literature covering the subject matter, comparative analysis and elements of case studies.

The paper is structured into five parts. Following the introduction, the essence of Buddhism and the major characteristics of Buddhist economics are explained in the first section. The next section concerns the topic of Buddhist enterprises and confronts this notion with the conception of social enterprise. Then some examples of the implementation of Buddhist teachings to business are presented and, finally, the main findings are given leading to the conclusion.

\section{The emergence of Buddhist economics and its major characteristics}

Buddhism was founded in the late $6^{\text {th }}$ century BCE and is the fourth largest religion in the world. It is a system of values which has a paradigmatic concern with human development, especially in a sustainable way (Saengsakorn, 2018). Four principles, called the Four Noble (Aryan) Truths, contain the essence of the Buddha's teachings (Bhikkhu, 1999; Daniels, 2010):

6. Suffering (dukkha) exists including birth, old age, sickness, death, anger, jealousy, worry, anxiety, despair, dissatisfaction, and discontent (Tomer, 2017).

7. The cause of suffering is craving (The Buddhist Centre).

8. There is a need for and a way out of suffering: it is required to gain an understanding of important life truths (Tomer, 2017).

9. Suffering has a cause to bring about its end; this Truth charts the method for attaining the end of suffering, known as the Noble Eightfold Path.

The Eightfold Path details the multifaceted nature of changes in mental processes, patterns and thoughts, actions and behaviour that are required for progress towards reducing suffering (Tomer, 2017). It consists of eight practices: 
1. right view: seeing in line with the truth,

2. right resolve: thinking in ways that will lead to well-being,

3. right speech: speaking in line with the truth,

4. right conduct (action): being correct and upright in one's activities,

5. right livelihood: maintaining oneself in ways that are honest and proper,

6. right effort: exerting oneself in line with all that is good,

7. right mindfulness: always being mindful of the person or topic that forms one's point of reference,

8. right concentration: keeping the mind correctly centred in line with the principles of the truth, not letting it fall into the ways of wrong concentration (Dhammadharo, 1995).

The ground rule of Buddhism is ahimsa ("doing no harm", "non-violence"). People who respect this principle avoid violence towards others because of the belief that they are interdependent both with Nature and with all other creatures. According to this view, nobody exists as a separate being, and so each person's quality of life is dependent on others' happiness and on the condition of the Earth. Human interdependence with the planet should provide a motivation to care for nature (Chinchore, 2005; Kietliński, 2005). At the heart of Buddhism is living mindfully, involving the kind of understanding about oneself and others that help people live compassionately and in peace and joy (Tomer, 2017).

Because the principles of Buddhism can refer to human behaviour in any aspect it has led naturally to the transfer of Buddha's teachings to economics (a science about the economic behaviour of a human being), and, subsequently, to the emergence of Buddhist economics (Tusińska, 2019). In Western thought, it begins with E.F. Schumacher who based his economics on the central values of simplicity and non-violence. The Buddhist requirement of "Right Livelihood" means there is Buddhist economics with the goal of purification of character and liberation (Brown, Zsolnai, 2018). He argued against the industry's brutality and its despoiling of both the environment and the human spirit (Schumacher, 1966, 1973).

An equals sign cannot be put between Buddhist economics and traditional Buddhist thought. The problems in ancient times are different from those of the contemporary economy, thus current processes cannot be meaningfully explained on the basis of the old wisdom (Brown, Zsolnai, 2018). However, the concept of Buddhist Economics can be found in Buddha's teaching. As an example, gratitude toward other beings and a sense of regret about harming others call for an environmental and social assessment of goods and industries. Every undertaking should be set up and located in the context of the entire universe, with a focus on environmental and social aspects (Zsolnai, 2016; Saengsakorn, 2018).

Neither is Buddhist Economics synonymous with the economics of Buddhism. The latter is a study of how Buddhists organise their economic life in real-world settings, whereas the former is a modern discourse (Zsolnai, 2016) that utilises elements of Buddhist thought to construct a model of the economy (Saengsakorn, 2018), an alternative to mainstream Western economics.

Another representative of Buddhist economics, the monk P.A. Payutto, claimed that people are born in a state of ignorance of how to live. Having no guidance of knowledge or wisdom, humans simply follow their urges. Two types of cravings are recognised by the author, namely tanhā (the desire for pleasurable objects), and Chanda (the desire for 
well-being), and respectively two kinds of consumption can be distinguished (wrong and right). Desires can be controlled by an appreciation of moderation and the objective of well-being (Zsolnai, 2016). The wisdom of moderation is at the very heart of Buddhism (Tomer, 2017). Payutto also presented his view on production which was that it is always accompanied by destruction. This can be acceptable in some cases, namely when the value of the thing produced outweighs the value of that which is destroyed otherwise, it is better to refrain from production (Zsolnai, 2016; Payutto, 1994).

Both consumption (C) and production (P) are also pondered by S. Inoue (1997). He suggests that the former can be ranked according to four levels: $\mathrm{C} 1$ (consumption of products vital for life), $\mathrm{C} 1$ (consumption of goods that are not urgently needed but make living better), C3 (consumption of products which are not indispensable), C4 (consumption of unnecessary or even harmful goods). The second can be evaluated also according to four levels: P1 (production having a negligible negative impact on the environment), P2 (a minimal negative impact), P3 (some negative impact), and P4 (production involving a great deal of negative impact (Zsolnai, 2016). Variables representing the impact of these processes on the natural environment have been assigned to individual levels of consumption and production. The combination of these variables is presented in Table 1.

Table 1. Environmental and social assessment categories for production and consumption

\begin{tabular}{|c|r|r|r|c|}
\cline { 2 - 5 } \multicolumn{1}{c|}{} & P1 & P2 & P3 & P4 \\
\hline C1 & 1 & 2 & 3 & 4 \\
\hline C2 & 2 & 4 & 6 & 8 \\
\hline C3 & 3 & 6 & 9 & 12 \\
\hline C4 & 4 & 8 & 12 & 16 \\
\hline
\end{tabular}

Source: Inoue (1997), quoted from Zsolnai (2016)

The combination (Table 1) determines if a given production of is environmentally-friendly and the consumption is truly indispensable. The lower the number associated with a combination, the better it is for the Earth and humans. The variables attributed to individual levels of consumption and production grow faster with each subsequent level, which shows that the cumulative negative impact of the processes on the natural environment is greater than would appear from a simple summing of effects.

Perspective should be always intergenerational; because future societies have no voting power, the current one should calculate the value of the detriment to the next generation in taking decisions (Brown, Zsolnai, 2018). In other words, goods and services should be made and consumed to meet vital needs and improve the quality of life while the use of natural resources and emissions of toxic and other waste should be kept at levels that will not jeopardise the ability to meet the requirements of future generations (Zsolnai, 2016; Daniels, 2007).

The described rules might be guidelines in curing mankind of such problems as overconsumption, welfare malaise, economic inequality, the destruction of nature and global warming. Thus, this economics can be relevant not only for Buddhist countries but also for Western ones (Brown, 2017).

The mixture of views presented above has a common denominator: orthodox economics connects the suffering of an individual to the suffering for all people, and general 
welfare depends on the well-being of each person and of nature. By measuring how economic activities affect the environment and other people, Buddhist economics supports the ground rule of ahimsa (Brown, Zsolnai, 2018). The difference between mainstream economics and the Buddhist approach can be demonstrated as two models in opposition:

1. A maximising framework as represented by mainstream Western economics. It tends to build a world where "bigger is better" and "more is more" (maximum profit, more desires, bigger markets, instrumental use, and self-interest) (Saengsakorn, 2018).

2. A minimising framework as represented by Buddhist economics. Suffering, desires, violence, instrumental use, and self-interest have to be reduced here. The statements "small is beautiful" and "less is more" express the essence of this approach to economic dilemmas (Saengsakorn, 2018).

Thus, Buddhist economics can be described as an alternative to the materialistic and individualistic mindset embracing the individual (micro-micro), micro (a company), macro (a country) and the global levels of the economy. Heterodox economists are trying to answer the following questions: How can individuals (as consumers, employees or investors) behave (micro-macro level)? How could enterprises organise their activities in keeping with Buddhist teachings (micro-level)? How would an economy driven by Buddhist values function (macro-level)? What are the guiding principles of Buddhist economic policies at the national (macro) and global levels? (Brown, Zsolnai, 2018). An attempt to answer the second question is further considered.

Buddhist enterprise, its nature and relation with social enterprise: a theoretical approach

According to Buddhism, ahimsa should be the main guiding value, not only in everyday life but also in business. Benefits and losses should be interpreted by entrepreneurs or managers not only in monetary terms or applied only to humans. Payutto (1994) collected the important messages of the Buddha for householders and business people. According to the monk, wealth:

1. should not be acquired by exploitation, but through effort and wise action; it should be acquired in a morally sound way (acquisition);

2. should be saved and protected as an investment for the further development of livelihood and as insurance against potential odds; when accumulated wealth exceeds these requirements, it might be used (safekeeping) to support alternatively: oneself and one's family, the interests of fellowship and social harmony (such as receiving guests, or in activities of one's friends or relatives) or good works, such as community welfare projects (use) (Brown, Zsolnai, 2018; Payutto, 1994);

3. should not become an obsession, a reason for tribulation or apprehension; it should rather be related to an understanding of its true benefits and limitations and dealt with in a way leading to personal development (mental attitude) (Payutto, 1994).

What should be stressed is that the Buddha never imposed limitations on his lay followers' efforts to be successful but he encouraged them to strive for success (Rahula, 2008). However, nothing runs more counter to the spirit of Buddhism than craving for and then clinging to possessions. Affluence should both bring peace of mind and enable charity. 
On the basis of the guidelines above, however, it is clear that what will be done with the benefits, including financial ones, is essential. Any person, including an entrepreneur, can become a Bodhisattva. There are various ideas of Bodhisattva characteristics (Binh, 2019) but, generally, they are enlightened beings who have put off entering paradise in order to help others attain enlightenment. The Bodhisattva can be a layman whose problems can be helpful on the way to enlightenment because they motivate her/him to self-improve. Such an exemplar can be pursued following any profession but entrepreneurship is desirable in particular (Karczewski, 2010). In the context of entrepreneurship, Kriger and Dhiman mention the idea of servant leadership. The core values of servant leaders include integrity, altruism, humility, empathy and healing, personal growth, fairness and justice and empowerment (Kriger, Dhiman, 2018). All of these are emphasised in Buddhism where particular stress is placed on integrity (right intention and motivation), empathy, healing (compassion and loving-kindness), and fairness and justice.

Buddhist teachings can be implemented by enterprises regardless of profile, but industries that pose a risk of damage to the environment drop out in a natural way (Tusińska, 2019). Business is worth running only if it works by the principle of "doing no harm" and reduces somehow the suffering of those who are affected, a community, employees, shareholders or the natural environment. According to Brown and Zsolnai (2018), if an enterprise meaningfully employs such principles as care and compassion, non-violence, generosity, suffering minimisation and want-reduction, it can be categorised as a "Buddhist enterprise". Such companies, through their activity, promote sustainable development, environmental protection and social inclusion. Success in business must, in the final analysis, serve the common good.

The definition of Buddhist enterprise is quite general and not very complicated; it does not result from any formal premises which initially allows us to conclude that almost every concerned enterprise can implement Buddhist teachings. It may or may not be based in a Buddhist country. Similarly, it may or may not be managed by a Buddhist. However, the manager (or the CEO) must be a person implementing the idea of servant leadership described above. Buddhist values can also be implemented regardless of the size, organisational and legal forms of enterprises, but given its ethical foundation, social entrepreneurship (SE) seems to be a form especially well-suited to Buddhists. As opposed to the notion of Buddhist enterprise, there are many definitions of SE in the world of practice (Nicolopoulou, 2014). The common issue in all of them is the social aim, but what remains debatable is the proportion between "social" and "entrepreneurship". Narrow definitions limit SE to the application of business activities and skills to organisations working in the third sector. Broader definitions seem to include a whole spectrum of activities within the SE umbrella from businesses' CSR practices to innovation and entrepreneurialism in NGOs and charities (Austin et al., 2006).

The core of SE is a social enterprise (social entrepreneurship organisation). A number of debates concern their scope and purpose as a subject of activity. These discussions have been determined by national antecedents, including the key role of institutional and historical factors which vary between countries or regions (Starnawska, Brzozowska, 2018). In this part of the world, European institutions' or organisations' opinions should be guidelines. According to the EC (European Council 2013), "social enterprise" means an undertaking, regardless of its legal form, which: 
1. in accordance with its Articles of Association, Statutes or with any other legal document by which it is established, has as its primary objective the achievement of measurable, positive social impacts rather than generating profit for its owners, members and shareholders, and which provides services or goods which generate a social return and/or employs a method of production of goods or services that embodies its social objective;

2. uses its profits first and foremost to achieve its primary objective and has predefined procedures and rules covering any distribution of profits to shareholders and owners that ensure that such distribution does not undermine the primary objective;

3. is managed in an entrepreneurial, accountable and transparent way, in particular by involving workers, customers and stakeholders affected by its business activities.

The Council puts first such formal aspects as articles of association or statute but nothing similar has been included in the definition of a Buddhist enterprise. EMES (European Research Network) (Klucz..., 2019) formulates two groups of criteria defining a perfect social enterprise which are consistent with the EESC (European Economic and Social Committee, 2017) approach (Table 2).

Table 2. The criteria for a perfect social enterprise

\begin{tabular}{|l|l|}
\hline \multicolumn{1}{|c|}{ Economic criteria } & \multicolumn{1}{c|}{ Social criteria } \\
\hline - a relatively continuous, regular activity & - grass-roots nature of the initiative \\
based on market instruments (they are & - community nature of the activity \\
formally-organised enterprises taking & - each member has one vote in decision- \\
economic risk) & making, regardless of their financial \\
- the autonomy of decision; independence & contribution \\
from public institutions & - all events are decided through democratic, \\
- freedom of membership and at least a small & participatory processes \\
part of the staff working as volunteers & \\
\hline $\begin{array}{l}\text { - set to meet their members' and/or community needs (through the market by producing } \\
\text { goods and providing services) }\end{array}$ \\
\begin{tabular}{l} 
not driven by profit and any profits are reinvested into the company and into society \\
\hline
\end{tabular}
\end{tabular}

Source: based on Klucz (2019), EESC (2017), SENSENET (2019)

To become a "social enterprise" not every single criterion (Table 2) must be fulfilled by a given entity (a majority is enough). According to EESC, social enterprises are inspired by common values such as solidarity, social cohesion, the primacy of the individual over the capital, and social responsibility (European..., 2019). Similar goals underlie the functioning of every Buddhist enterprise, although environmental protection activities seem to be more exposed in the case of the latter. The correspondence between Buddhist and social enterprises can be identified in the process of verification of some statements (Table 3).

To consider stricter criteria (Table 3) to distinguish between Buddhist and social enterprises is not possible. "Buddhist enterprise" seems to be a broader notion than "social enterprise". The latter is in alignment with the Buddha's teachings insofar as it emphasises both profit and an ethical foundation. Commitment to a social mission, instead of maximising profits, can be perceived as the Buddhist rule not to exploit others. While the ethical foundation of social enterprise is generally understood to be a commitment to a social or environmental mission, there is nonetheless considerable scope for overlap 
with Buddhist values, such as compassion or mindfulness (Nunamaker, 2014). It seems that social enterprises operate according to Buddhist principles, whereas not every Buddhist enterprise is a social enterprise since they have not been formally established as such.

Table 3. Buddhist enterprises versus social enterprises

\begin{tabular}{|l|c|c|}
\hline \multicolumn{1}{|c|}{ Statement/feature } & $\begin{array}{c}\text { Buddhist } \\
\text { enterprises }\end{array}$ & $\begin{array}{c}\text { Social } \\
\text { enterprises }\end{array}$ \\
\hline They are businesses set up primarily to benefit people and the planet & optionally & yes \\
\hline $\begin{array}{l}\text { A document by which enterprise is established matters which has as } \\
\text { its priority the achievement of positive social impacts }\end{array}$ & no & yes \\
\hline $\begin{array}{l}\text { They can take the form of not-for-profit and non-governmental } \\
\text { organisations }\end{array}$ & optionally & no \\
\hline $\begin{array}{l}\text { They can take the form of for-profit organisations but the economic } \\
\text { activity does not have profit as its principal goal }\end{array}$ & yes & yes \\
\hline They do not exist as any particular legal form & yes & yes \\
\hline They exist in Buddhist and non-Buddhist countries alike & yes & yes \\
\hline They can be managed by Buddhists or non-Buddhists & yes & yes \\
\hline
\end{tabular}

Source: author

\section{Buddhist teachings in practice}

Despite some corporations' official pro-human or pro-environment declarations, their priority is not to meet genuine human needs but to generate profits. Most contemporary enterprises seem to promote such values as attachment, delusion and pride which are the opposite of what Buddhism cultivates. The world view of the majority of businesspeople reflects, to a considerable extent, the principles of so-called mainstream economics but there are also many exceptions.

The first of these exceptions is a group of over 2500 companies in 150 industries in the world that have been awarded the B Corp certificate by the American NGO B Lab. The group includes organisations that resolve crucial social problems, and the basis of their operation is a collaboration with partners based on symbiosis. Having in mind that the most challenging issues cannot be solved by the public and third sector alone, the B Corp community works towards greater equality, reduced poverty, a healthier environment, stronger communities, and the creation of more high-quality jobs. Using the power of business, B Corps treat profits as a means to have a positive impact on employees, communities, and the environment (Benefit Systems, 2019; Certified B Corporations, 2019a).

To get a certificate, an enterprise must score a certain minimum number of points in various categories (such as an attitude towards workers, positive impact on the environment and implementation of given social goals). Although any company, regardless of size, structure or line of business, can apply for B Corp status, the majority of certified entities are small and medium-sized organisations - but not all of them. One of the exceptions is 'Benefit Systems', the only company in Poland (and the first company in Central and Eastern Europe) awarded the certificate. It offers non-financial benefits (sports, cultural and entertainment as well as cafeteria programs) supporting employers 
in creating attractive jobs. The company also helps reduce employment costs (thanks to, for example, less sick-leave for physically active employees). Their partners are Polish local entrepreneurs running recreational and sports centres who provide the services and also benefit from cooperation. The company cooperates on the MultiSport program with four thousand partners. Benefit System's flagship product (the MultiSport card) has nearly one million users in Poland, and $78 \%$ of them attested that it has a positive impact on the frequency of physical activity. Since 2015, the company has been running programs that support organisations or people in need (Dobry MultiUczynek, Active MultiSport Schools, MultiSport Senior card). The company strives to operate in an Earth-friendly way thanks to premises that meet ecological standards, and the use of ways of limiting the production of waste paper and electricity consumption (Benefit Systems, 2019; Certified B Corporations, 2019b). It can be stated that the company works for the common good, but in the founding documents, it is impossible to find confirmation about social enterprise statutes (Benefit Systems, 2020).

Another member of the B Corp community is Patagonia, a worldwide clothing company, which explores sustainable methods of production and materials including organic cotton, hemp, polyethylene terephthalate, and even PET (DeLeon, Guides, 2018). Among the most direct ways of limiting ecological impacts is with goods that last for generations or can be recycled. Environmental issues are also advocated by the company on its website (DeLeon, Guides, 2018; Patagonia Action Works, 2019) and as far back as 1986, Patagonia began donating 10\% of its profits to grassroots organisations (Patagonia, 2015). In just the last few years, the company has expanded its used clothing program, increased its investment in sustainable start-ups and launched a kind of activist hub to connect its customer base directly with grassroots environmental organisations. Moreover, Patagonia has sued the President Trump administration for its public land policy. Recently, CEO Rose Marcario announced it was giving USD 10 million in tax cuts to grassroots environmental organisations (Beer, 2019). The adopted business model is largely compatible with the demands of the degrowth movement (minimising production and consumption) and Patagonia, as a member of various organisations working for responsible fashion, is undoubtedly a company implementing Buddhist values. However, the company cannot be classified as a social enterprise because there are no formal reasons for this.

Some "servant leaders" from Buddhist countries are also worth mentioning. Such leaders include Konosuke Matsushita, the founder of Matsushita Electric (MEC, the owner of Panasonic), and Kazuo Inamori, a Japanese philanthropist, entrepreneur, Buddhist priest, founder of Kyocera and KDDI Corporations, and chairman of Japan Airlines.

By almost any standard, Matsushita (1894-1989) was a remarkable entrepreneur during a time when his nation lost the Second World War and he experienced numerous personal tragedies. In 1946, he resigned all his operating responsibilities for MEC and founded the PHP Institute (short for "peace and happiness through prosperity"). He then spent the majority of the rest of his life training future leaders in Japan who would take the philosophy of PHP forward into leadership positions in Japanese society, irrespective of their political party. Embedded in PHP principles, as well as the philosophy and values espoused personally by Matsushita, many of the aspects of the Buddha's eightfold path in action may be found (Kriger, Dhiman, 2018).

Kazuo Inamori believes that taking care of employees and making sure they are happy is a crucial aspect of management. He has used this philosophy to set up the electronics 
company Kyocera Corp, create the phone carrier KDDI Corp, and rescue Japan Airlines Co from bankruptcy. When Inamori was proclaimed CEO of Japan Airlines, he was 77 and had no experience in the aircraft industry. The next year, he returned the carrier to profit, then he relisted it on the Tokyo stock exchange claiming the secret was to transform the workers' mentality. Namely, he entered the office without salary and in a brochure given to each staff member he declared the devotion of the company to their growth. In his small book, Inamori also explained the significance of their work and outlined Buddhist-inspired principles for how employees should live. This made them proud of the airlines and incentivised to work harder. Inamori claims that if staff are happy, they will work better and earnings will improve. Companies should not be ashamed to make profits if they are pursued in a way that benefits society (Paulo, 2018; Redmond, Taniguchi, 2019; Todd, 2018). Japan Airlines is another example of a company which cannot be classified as social but is undoubtedly a Buddhist enterprise.

Since the philosophy and practice of Buddhism span most of the globe, it has come to infuse the belief system, values and decision-making of numerous business leaders in both the East and the West.

\section{Conclusion}

Acknowledging the interdependence of individuals and nature, Buddhist economics guides societies in using resources to provide a comfortable and enjoyable life worldwide, while living in harmony with communities and ecosystems (Brown, Zsolnai, 2018). Buddhist economics seems to be relevant not only for Buddhist countries but also for Western economies in solving their problems of overconsumption and destruction of the natural environment. In this context, the business has a role to play. Enterprises must respect ecological boundaries and provide goods that people need to live sustainably and comfortably whereas their workers should have a balanced life with meaningful experience (Brown, Zsolnai, 2018). Mindfulness is always crucial to making a profit and a resolution not to exploit others should be made.

Although profits may rise, they should be treated as a by-product rather than the main purpose of economic activity. Possessing material wealth is not forbidden by Buddhists as they only remind people not to become attached to material possessions and to share their wealth with others.

There are new businesses on the economic scene which meet the above requirements, they are Buddhist enterprises. They measure their business success through social engagement and care for the natural environment. Because social enterprise focuses on a social or environmental mission rather than maximising profits it is a form especially well-suited to Buddhism. However, an equals sign cannot be put between social enterprise and Buddhist enterprise. To be categorised as a "Buddhist enterprise" it is enough to act employing Buddhist values. This means that the company can be established to pursue profit maximisation, and in the course of the operation it can adopt a Buddhist profile, whereas a document by which social enterprise is established has as its priority the achievement of positive social impacts. In simplified terms, social enterprises non-deliberately apply Buddhist teachings to business and not every Buddhist enterprise operates as a social one. 
Both theoretical arguments and the examples discussed (Benefit Systems, Japan Airlines) confirm the thesis that Buddhist enterprises are not the same as social enterprises but regardless of their legal or organisational forms, the examples described here lead to an awareness that business activity can be the way to an upstanding life.

Mindfulness and generosity seem to work in the business. Caring organisations can be rewarded for their efforts and the higher costs of their socially and environmentally friendly behaviour, by their power to create commitments among owners, managers and employees (e.g. avoiding opportunistic behaviour, willingness to work more and/ or harder for lower salaries) and to establish relationships of trust with customers and stakeholders.

\section{References}

Austin, J.E., Stevenson, H., Wei-Skillern, J. (2006). Social and commercial entrepreneurship: Same, different, or both? Entrepreneurship Theory and Practice, 30(1), 1-22. doi: 10.5700/rausp1055

Beer, J. (2019, 1 April). Exclusive: Patagonia is in business to save our home planet. Retrieved from: https:// www.fastcompany.com/90280950/exclusive-patagonia-is-in-business-to-save-our-home-planet

Benefit Systems. (2019, 15 May). Benefit Systems as the only Polish company with the B Corp title Retrieved from: https://www.benefitsystems.pl/en/about-us/press-centre/press-release/benefit-systems-jedyna-polska-firma-z-tytulem-b-corp/

Benefit Systems. (2020; 15 May). Dokumenty korporacyjne. Retrieved from: https://www.benefitsystems. $\mathrm{pl} /$ dla-inwestora/lad-korporacyjny/dokumenty-korporacyjne/

Bhikku, T. (1999; 2019, 15 March). The Four Noble Truths: A Study Guide. Access to Insight (BCBS Edition). Retrieved from: http://www.accesstoinsight.org/lib/study/truths.html

Binh, T.T. (2019). Different Ideas of Bodhisattva Characteristics. The Journal of The International Buddhist Studies College, 3(1), 1-17.

Brown, C. (2017). Buddhist Economics: An Enlightened Approach to the Dismal Science. Bloomsbury Publishing.

Brown, C., Zsolnai, L. (2018). Buddhist Economics: an Overview. Society and Economy, 40(4), 497-513. doi: 10.1556/204.2018.40.4.2

Certified B Corporations. (2019a, 15 May). BCorporation. Retrieved from: https://bcorporation.net/ about-b-corps

Certified B Corporations (2019b, 15 May). BCorporation. Retrieved from: https://bcorporation.net/directory/benefit-systems

Chinchore, M. (2005). The conception of AHIMSĀ in Buddhism: a Critical Note. Annals of the Bhandarkar Oriental Research Institute, 86, 103-109.

Dalai Lama, H., van den Muyzenberg, L. (2009). The Leader's Way: Business, Buddhism and Happiness in an Interconnected World. Broadway Books.

Daniels, P. (2010). Climate Change, Economics and Buddhism - Part I: An Integrated Environmental Analysis Framework. Ecological Economics, 10, 952-961.

Daniels, P. (2007). Buddhism and the Transformation to Sustainable Economies. Society and Economy, 29(2), 155-180. doi: 10.1556/SocEc.29.2007.2.3

Dhammadharo. (1995; 2019, 10 kwietnia). The Path to Peace and Freedom for the Mind (translated from the Thai by Thanissaro Bhikkhu). Access to Insight. Retrieved from: https://www.accesstoinsight. org/lib/thai/lee/pathtopeace.html

DeLeon, J., Guides, B. (2018; 2020, 15 maja). What Patagonia Teaches Us About Building a Brand That Lasts. Retrieved from: https://www.highsnobiety.com/p/patagonia-brand-history-highsnobiety-book/ 
European Council. (2013). Regulation (EU) No 1296/2013 of the European Parliament and of the council of 11 December 2013 on a European Union Programme for Employment and Social Innovation ("easi") and amending Decision No 283/2010/EU establishing a European Progress Microfinance Facility for employment and social inclusion). Article 2, point 1.

European Economic and Social Committee. (2019, 10 May). Retrieved from: https://www.eesc.europa. eu/en/members-groups/categories/social-economy-category.

European Economic and Social Committee. (2017). Recent Evolutions of the Social Economy in the European Union. Executive summary. Brussel. Retrieved from: https:/www.eesc.europa.eu/sites/ default/files/files/qe-04-17-876-en-n.pdf

Inoue, S. (1997). Putting Buddhism to Work. A New Approach to Management and Business. Tokyo, New York, London: Kodansha International Ltd.

Karczewski, L. (2010). Kulturowe uwarunkowania etyki biznesu w wybranych krajach azjatyckich. [Cultural determinants of business ethics in selected Asian countries]. Etyka Gospodarcza Orientu. Studia i Monografie. [Economic ethics of the Orient. Studies and Monographs], 272, 13-62.

Kietliński, K. (2005). Etyka w biznesie i zarzadzaniu. [Ethics in business and management]. Warszawa: Oficyna Ekonomiczna.

Klucz. Centrum Wspierania Przedsiębiorczości Społecznej (2019, 10 May). Retrieved from: https://inspro.org.pl/centrumklucz/cwps/start/przedsiebiorczosc-spoleczna/

Kriger, M., Dhiman, S. (2018). A Buddhist Theory of Organizational Leadership. In: G.E. Roberts, J.E. Crossman (ed.), The Palgrave Handbook of Workplace Spirituality and Fulfillment. Springer International Publishing.

Magnuson, J. (2016). From Greed to Wellbeing. A Buddhist Approach to Resolving Our Economic and Financial Crises. University of Bristol: Policy Press.

Nicolopolou, K. (2014). Social entrepreneurship between cross-currents: Toward a framework for theoretical restructuring of the field. Journal of Small Business Management, 52(4), 678-702. doi: https://doi.org/10.1111/jsbm.12130

Nunamaker, C.R. (2014; 2019, 20 May). Buddhism and Social Enterprise: creating a more compassionate economy. For presentation at the 14th Sakyadhita International Conference on 'Compassion and Social Justice' 23-20 June 2015 Yogyakarta, Indonesia. (2019, 20 May). Retrieved from: https:// www.academia.edu/14335266/Buddhism_and_Social_Enterprise_creating_a_more_compassionate_economy?email_work_card=title

Patagonia (2015, 9 September). Patagonia. Retrieved from: https:/www.patagonia.com/blog/2015/09/ our-earth-tax-patagonia-environmental-social-initiatives-2015/

Patagonia Action Works. (2019, 1 April). Patagonia. Retrieved from: https://www.patagonia.com/actionworks/\#!/choose-location/?referer=logo

Paulo, D.A. (2018, 18 December). How a Buddhist monk turned CEO revived Japan Airlines from bankruptcy. Channel News Asia. Retrieved from: https://www.channelnewsasia.com/news/cnainsider/ buddhist-monk-ceo-kazuo-inamori-save-japan-airlines-jal-bankrupt-11033866

Payutto, P. A. (1994). Buddhist Economics: A Middle Way for the Market Place. Bangkok: BuddhaDhamma Foundation. Retrieved from: http://www.urbandharma.org/pdf/Buddhist_Economics.pdf

Rahula, B.B. (2008). The Buddha's Teachings on Prosperity. Somerville, Mass: Wisdom Publications.

Redmond, T., Taniguchi, T. (2019, 15 May). The No. 1 business rule of a Buddhist billionaire: Make workers happy. The Sydney Morning Herald. Retrieved from: https://www.smh.com.au/business/ workplace/the-no-1-business-rule-of-a-buddhist-billionaire-make-workers-happy-20151105gkr92j.html

Saengsakorn, R. (2018; 2019, 15 May). Buddhist Economics as a Human Development's Paradigm. Retrieved from: https://www.semanticscholar.org/paper/Buddhist-Economics-as-a-HumanDevelopment\%E2\%80\%99s-Saengsakorn/1443b32c038b59fb7e95f16bdfcdb5fec0db7f66

Schumacher, E.F. (1966; 2019, 15 May). Buddhist Economics. Center for a New Economics. Retrieved from: https://centerforneweconomics.org/publications/buddhist-economics/ 
Schumacher, E.F. (1973). Small is beautiful. A study of economics as the people mattered. Blond \& Briggs. SENSENET. (2019). Enhancing diversity in social economy organisations and enterprises across the European Union - a state-of-the-art on existing practices. Executive Summary.

Starnawska, M., Brzozowska, A. (2018). Editorial Paper. Social Entrepreneurship and Social Enterprise Phenomenon: Antecedents, Processes, Impact across Cultures and Contexts. Journal of Entrepreneurship, Management and Innovation (JEMI), 14(2). doi: https://doi. org/10.7341/20181421

The Buddhist Centre. Four Noble Truths. (2020). https://thebuddhistcentre.com/text/four-noble-truths Tideman, S.G. (2016). Business as an Instrument for Societal Change: In Conversation with the Dalai Lama. Routledge: Greenleaf Publishing Book.

Todd, F. (2018, 29 December). Five Buddhist business leaders: From Alibaba co-founder to eBay's creator. Retrieved from: https://www.compelo.com/buddhist-business-leaders-alibaba-ebay/

Tomer, J.F. (2017). Why Buddhist economics is needed: overcoming large scale biophysical and socio-economic dysfunctions. Real-World Economics Review, 82, 143-158.

Tusińska, M. (2019). Buddhist Economics as a New Mindset at the Business Level. 'Economic and social development': 41st International Scientific Conference on Economic and Social Development: book of proceedings: Belgrade, 23-24 May 2019, 148-157.

Zsolnai, L. (2016). Buddhism and Economic Development. In: G.D. DeAngelis, T. Lewis (eds.). Teaching Buddhism. Oxford: Oxford University Press, 344-360.

Zsolnai, L. (2015). Post-Materialistic Business: Spiritual Value-Orientation in Renewing Management. Palgrave-Macmillan.

Magdalena Tusińska, PhD, the University of Economics in Katowice, Faculty of Economics, Department of Economics. Author is a lecturer on economics at the University of Economics in Katowice. She has published articles and books on the competitiveness of the economy, social-economic development, economic systems, the European Union, income inequality and poverty. She currently works on social inequality, especially in income dimension.

ORCID: https://orcid.org/0000-0001-9646-9628

\section{Address:}

Uniwersytet Ekonomiczny w Katowicach

Wydział Ekonomiczny

ul. 1 Maja 50

40-287 Katowice, Poland

e-mail: magdalena.tusinska@ue.katowice.pl 